\title{
MESIN ELEKTRIK PENYERUT ES BATU UNTUK MEMPERBAIKI EFISIENSI WAKTU PRODUKSI, DAN TEKSTUR HASIL PRODUK
}

\author{
Arif Banyu Adam**) dan Gempur Santoso*)
}

\begin{abstract}
Abstrak
Salah satu proses untuk menghaluskan es batu adalah dengan menyerutnya. Alat yang digunakan adalah mesin elektrik penyerut es. Tujuan utama mesin elektrik penyerut es batu ini untuk memperbaiki efisiensi waktu produksi yang berorientasi kepada konsumen. Untuk mengetahui tingkat kepentingan dan kepuasan konsumen terhadap proses pembuatan mesin elektrik penyerut es batu. Untuk itu permasalahan dapat dinyatakan: apakah dengan menggunakan mesin elektrik penyerut es batu memperbaiki efisiensi waktu produksi dan tekstur hasil produk serutan es. Dengan menggunakan metode deskriptif-komparatif, Metode yang menjelaskan dan melakukan perbandingan data hasil penelitian dari dua narasumber yang berbeda. Hasil perbandingan data penelitian ini sebagai dasar pembuatan mesin elektrik penyerut es. Kemudian prototype di uji cobakan untuk mengetahui tingkat kepuasan konsumen akan efisiensi waktu produksi dan tekstur hasil produk serutan es. Hasil penelitian menunjukan bahwa mesin penyerut es elektrik lebih efisiensi waktu dibandingkan dengan alat penyerut es dalam memproduksi serutan es.Dengan rata-rata yang manual dapat ditempuh dalam waktu 12,18 detik, Sedangakan yang menggunakan mesin elektrik penyerut es dapat ditempuh dengan waktu 5,49 detik, penyerutan es dengan berat es 300 gram dari hasil 30 test proses penyerutan es. dan hasil dari penyerutan antara mesin manual dan elektrik mengalami perbedaan dari 30 orang pengamat dapat disimpulkan bahwa mesin elektrik lebih halus hasil serutannya, dibandingkan penyerut manual. Konsumen dapat merasakan kepuasan terhadap produk yang telah diperbaiki, Oleh karena itu pembuatan produk maka harus memprioritaskan tingkat kepentingan dan kepuasan konsumen serta semua pihak terkait harus bekerja sama dengan baik sehingga output yang dihasilkan akan benar-benar dapat memuaskan konsumen.
\end{abstract}

Kata Kunci : Efisiensi Waktu Produksi, Tekstur Hasil Produk, Mesin Elektrik Penyerut Es Batu.

\section{PENDAHULUAN}

Mesin elektrik penyerut es batu adalah salah satu cara mempercepat dan meningkatkan suatu proses produksi, meskipun sampai saat ini masih banyak pedagang-pedagang minuman yang masih banyak menggunakan cara manual untuk menyerut es batunya. Mesin serut manual ini prosesnya lambat dan melelahkan.

Sebagai usaha peningkatan produktivitas kerja atau efisiensi kerja adalah jalan waktu yang digunakan untuk mengerjakan satu satuan berkurang berdasarkan tingkat konstanta tertentu. Untuk meningkatkan produktivitas kerja menurut Sritomo (1992) ditentukan oleh dua faktor, yakni faktor teknis dan faktor manusia. Faktor teknis akan memberi pengaruh yang besar terhadap usaha peningkatan produktivitas pada beberapa industri yang banyak menggunakan proses mekanisme atau otomasi. Jadi, penelitian mengenai produktivitas yang mengutamakan faktor teknis dititik beratkan pada aspek pengembangan teknologi dibandingkan manusianya. Sebaliknya, untuk usaha yang pengaruh teknis relatif kecil sedangkan faktor manusia sebagai unsur dalam sistem peningkatan produksi yang lebih menonjol, makai dengan usaha untuk peningkatan produktivitas akan lebih diarahkan pada segi manusia dari pada teknologi. Mulyasa (2006) mengemukakan bahwa efisiensi mengacu pada perbandingan antara input dengan output, tenaga dan hasil, perbelanjaan dan masukan, biaya serta kesenangan yang dihasilkan. Suatu kegiatan dikatakan efisien jika tujuan dapat dicapai secara optimal dengan penggunaan sumber daya minimal. Simon mengartikan efisiensi sebagai perbandingan antar input dan output, tenaga dan ahli, perbelanjaan dan masukan, biaya dan kesenangan yang dihasilkan. Engkoswara melihat efisiensi sekolah, sebagai kegairahan atau motivasi belajar yang tinggi, semangat kerja besar, kepercayaan berbagai pihak dan pembiayaan, waktu, dan tenaga yang sekecil mungkin tetapi hasil yang besar.

\footnotetext{
**) Mahasiswa Teknik Industri

*) Dosen Teknik Industri

Universitas PGRI Adi Buana Surabaya
} 
Sedangkan $H$. Emerson menerangkan bahwa : efisiensi adalah perbandingan yang terbaik antara input (masukan) dan output (hasil antara keuntungan dengan sumbersumber yang dipergunakan), seperti halnya juga hasil optimal yang dicapai dengan penggunaan sumber yang terbatas. Dengan kata lain hubungan antara apa yang telah diselesaikan. Sutalaksana (1979) mengatakan bahwa keberhasilan kerja (produtivitas) secara garis besar dipengaruhi dua kelompok yakni kelompok individual dan faktor situasional. Faktor individual datangnya dari diri pekerja itu sendiri dan sering kali sudah ada sebelum si pekerja yang bersangkutan datang ditempat kerjanya kecuali pendidikan dan pengalaman. Faktor situasional ini dapat diatur dan diubah baik dari segi sosial dan keorganisasian serta fisik pekerjaan yang bersangkutan. Sesuai observasi yang dilakukan peneliti diketahui bahwa tekstur hasil serutan es batu kurang lembut, peneliti berkesempatan untuk membuat mesin elektrik penyerut es batu, hal tersebut terbukti ketika proses penyerutan es batu menggunakan mesin elektrik penyerut es hasil tekstur buliran esnya lembut dan waktu produksi esnya cepat. Dari uraian latarbelakang masalah diatas peneliti akan melakukan penelitian dengan judul "Mesin Elektrik Penyerut Es Batu Untuk Memperbaiki Efisiensi Waktu Produksi, Dan Tekstur Hasil ProduK"

\section{METODE PENELITIAN}

Pada penelitian ini menggunakan dua jenis metode yaitu metode observasi dan metode wawancara, obyek penelitian ini adalah penjual es yang berada dijalan raden wijaya sidoarjo, populasi dari penelitian ini adalah pedagang es yang berada dijalan raden wijaya sidoarjo dengan jumlah 5 penjual es, sedangkan yang menjadi sempel adalah 3 penjual es yang berada dijalan raden wijaya sidoarjo.

Metode Analisis data yang digunakan adalah metode deskriptif-komparatif. Metode deskriptif komparatif adalah metode dengan menjelaskan dan melakukan perbandingan data hasil penelitian dari dua narasumber yang berbeda.

Rumus persentase :

$$
P=\frac{f}{N} \cdot 100 \%
$$

Keterangan :

P : persentase

F : : frekuensi data

N : jumlah sampel yang dioleh

$$
E K=\frac{W K E}{J K Y T} \cdot 100 \%
$$

$\begin{array}{llll}\text { Keterangan } & : \\ \text { EK } & \text { : Efisiensi Kerja } & \\ \text { WKE } & : \text { Waktu Kerja Efektif } & \\ \text { JKYT } & : \text { Jumlah Kerja Yang } \\ & \text { Tersedia } & \end{array}$

\section{Analisis Efisiensi Waktu Memproduksi Serutan Es.}

Hasil efisiensi waktu produksi dapat dilihat pada tabel 1 dibawah ini.

Tabel 1. Efisiensi waktu produksi serutan es antara manual dan elektrik.

\begin{tabular}{|l|l|}
\hline $\begin{array}{l}\text { Manual } \\
\text { Rata-rata } \\
\text { (detik) }\end{array}$ & $\begin{array}{l}\text { Elektrik } \\
\text { Rata-rata } \\
\text { (detik) }\end{array}$ \\
\hline 12,18 & 5,49 \\
\hline
\end{tabular}

Pada tabel diatas dapat disimpulkan hasil mesin penyerut es elektrik lebih efisiensi waktu dibandingkan dengan alat penyerut es dalam memproduksi serutan es. Dengan rata-rata yang manual dapat ditempuh dalam waktu 12,18 detik, sedangakan yang menggunakan mesin elektrik penyerut es dapat ditempuh dengan waktu 5,49 detik, penyerutan es dengan berat es $300 \mathrm{gram}$ dari hasil 30 test proses penyerutan es.

\section{Analisis Tekstur Hasil Serutan Es.}

Hasil analisis serutan es disajikan pada tabel 2 dibawah ini.

Tabel 2.Hasil Serutan Es.

\begin{tabular}{|l|l|l|}
\hline Tekstur & Manual & Elektrik \\
\hline Halus & $4(13,33 \%)$ & $30(100 \%)$ \\
\hline Kasar & $26(86,67 \%)$ & $0(0 \%)$ \\
\hline
\end{tabular}

presentase hasil dari penyerutan antara mesin manual dan elektrik mengalami perbedaan dari 30 orang pengamat dapat 
disimpulkan bahwa mesin elektrik lebih halus hasil serutannya dibandingkan penyerut manual. Dimana dihasilkan $100 \%$ halus menggunakan mesin elektrik berbanding $13,33 \%$ apabila menggunakan penyerut manual.

\section{HASIL DAN PEMBAHASAN}

Proses pengujian penyerut es dengan menggunakan penyerut manual dan mesin elektrik disajikan pada tabel 3 .

Tabel 3. Hasil Penelitian Proses Pengujian Penyerut Manual Dan Mesin Elektrik Penyerut Es.

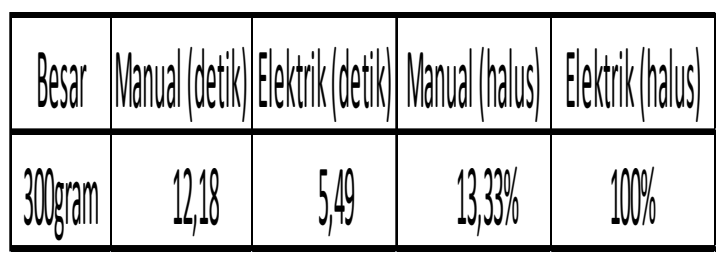

Pada tabel 3 diatas menujukkan bahwa hasil pengujian mesin elektrik penyerut es lebih efisiensi waktu produksi dan tingkat hasil serutan es lebih halus dibandingan dengan penyerut es manual. Dengan berat es 300 gram dapat ditempuh dengan waktu 12,18 detik apabila menggunakan penyerut es manual sedangkan apabila menggunakan mesin elektrik penyerut es dapat ditempuh dengan waktu 5,49 detik. Dan tingkat kehalusannya $13,33 \%$ apabila menggunakan penyerut es manual sedangkan menggunakan mesin elektrik penyerut es mencapai $100 \%$ tingkat kehalusannya. Dengan demikian mesin elektrik penyerut es ini dapat dikatan produktif dalam menyerut es.

\section{Pembahasan Efisiensi Waktu Produksi}

Berdasarkan hasil uji test dari proses pnyerutan es, efisiensi waktu yang didapat lebih cepat dari pada produk yang sebelumnya. bahwa produk tersebut mengalami peningkatan. Didapat dari 30 hasil penyerutan dengan menggunakan mesin elektrik penyerut es.

Efisiensi adalah tingkat perbandingan antara masukan (input) dengan hasil (output) yang dicerminkan dalam rasio atau perbandingan diantara keduanya. Jika output lebih besar dari input maka dapat dikatakan efisiensi dan sebaliknya jika input lebih besar dari output maka dikatakan tidak efisien. Jadi tinggi rendahnya efisien ditentukan oleh besar kecilnya rasio yang dihasilkan. (Riki
Satia Muharam, Administrasi Negara (catatan kuliah, 2005).

Mulyasa (2006) mengemukakan bahwa efisiensi mengacu pada perbandingan antara input dengan output, tenaga dan hasil, perbelanjaan dan masukan, biaya serta kesenangan yang dihasilkan. Suatu kegiatan dikatakan efisien jika tujuan dapat dicapai secara optimal dengan penggunaan sumber daya minimal. Simon mengartikan efisiensi sebagai perbandingan antar input dan output, tenaga dan ahli, perbelanjaan dan masukan, biaya dan kesenangan yang dihasilkan. Engkoswara melihat efisiensi sebagai kegairahan atau motivasi belajar yang tinggi, semangat kerja besar, kepercayaan berbagai pihak dan pembiayaan, waktu, dan tenaga yang sekecil mungkin tetapi hasil yang besar.

Sedangkan $\mathrm{H}$. Emerson menerangkan bahwa : efisiensi adalah perbandingan yang terbaik antara input (masukan) dan output (hasil antara keuntungan dengan sumbersumber yang dipergunakan), seperti halnya juga hasil optimal yang dicapai dengan penggunaan sumber yang terbatas. Dengan kata lain hubungan antara apa yang telah diselesaikan.

Pengembangan produk ini telah memenuhi kepentingan dan kepuasan, karena konsumen merasakan kepuasan terhadap mesin elektrik penyerut es. Hasil pengembangan produk mesin elektrik penyerut es ini memiliki dampak positif. Yakni perbandingan efisiensi waktu produksi antara produk alat penyerut es dan mensin elektrik penyerut es yang semakin cepat dan baik waktu serut yang dibutuhkan.

Konsumen menganggap prototype hasil pengembangan mesin elektrik penyerut es ini lebih baik dibandingkan yang sebelumnya dengan rata-rata waktu 5,49 detik untuk setiap kali penyerutan. Oleh sebab itu atribut prioritas kepuasan produk harus dipertimbangkan dalam pengembangan produk mesin elektrik penyerut es.

\section{Pembahasan Tekstur Hasil Serutan Es.}

Dilihat dari hasil uji test dari proses penyeutan es. tekstur dari hasil proses penyerutan es lebih halus dan seragam di bandingkan dengan menggunakan penyerut manual. Hasil dari penyerutan antara alat 
penyerut es manual dan mesin elektrik penyerut es mengalami perbedaan dari 30 orang pengamat. Tekstur serutan yang seragam dan mempunyai ukuran yang sama sehingga output yang dihasilkan hasilnya bagus.

Tekstur es yang halus dan seragam terlihat saat penyerutan es dilakukan dengan mesin elektrik penyerut es, ini dikarenakan proses serutnya yang cepat. Produk pengembangan ini telah memenuhi kepentingan dan kepuasan, karena konsumen merasakan kepuasan terhadap tekstur es yang dihasilkan dari mesin elektrik penyerut es.

Hasil pengembangan produk mesin elektrik penyerut es ini memiliki dampak positif. Konsumen menganggap prototype hasil pengembangan mesin elektrik penyerut es ini lebih baik dibanding alat penyerut es. Oleh sebab itu atribut prioritas kepuasan produk harus dipertimbangkan dalam pengembangan produk mesin elektrik penyerut es.

\section{SIMPULAN DAN SARAN \\ Simpulan}

Berdasarkan hasil uji test antara penyerut es manual dan mesin elektrik penyerut es terjadi peningkatan efisiensi waktu produksi serutan es yang baik dan cepat. Dengan rata-rata berat es batu 300 gram apabila menggunakan penyerut manual dapat ditempuh dengan waktu 12.18 detik sedangkan menggunakan mesin elektrik penyerut es dapat ditempuh dengan waktu 5.49 detik. Produk ini berpengaruh positif terhadap penjual es yang ingin meningkatkan hasil penjulan esnya.

Mesin elektrik penyerut es yang berpengaruh terhadap kepuasan konsumen yaitu mesin elektrik penyerut es menghasilkan serutan es yang halus, bisa dioperasikan, dimensi dynamo motor dengan menggunkan van belt yang tahan lama, berat dynamo, kontruksi kuat dan rapi, mudah dipindah-pindahkan, mudah untuk dibongkar pasang, bentuk dudukan dynamo, tahan lama, mudah dibersihkan dan desain ini dapat digunakan dengan mesin maupun manual.

\section{Saran}

Analisis prioritas dapat dijadikan dasar yang harus diperhatikan untuk membuat produk mesin elektrik penyerut es ini dengan menggunakan komposisi yang sudah diperbaiki karena memberikan kepuasan yang lebih baik. Agar penelitian selanjutnya menelitibagaimana mesin elektrik ini bias digunakan selain untuk penyerutan es batu. Maka pembuatan produk yang ditambah yaitu tambahan meja panjang $65 \mathrm{~cm}$ dan lebar $40 \mathrm{~cm} \times$ tinggi $60 \mathrm{~cm}$. Dalam rangka mengembangkan produk yang memenuhi kepuasan konsumen, penambahan 4 roda gepeng pada kaki rangka agar mudah untuk dipindah-pindahkan. Proses pengembangan produk dibatasi dengan penambahan biaya tidak boleh menaikkan harga jual produk.

Dalam melakukan pengembangan produk ini semua pihak yang terkait harus bekerja sama dengan baik agar semua proses pembuatan produk berjalan dengan lancar.

\section{DAFTAR PUSTAKA}

Gempur Santoso, Ergonomi manusia, peralatan dan lingkungan, Prestasi Pustaka, Jakarta, 2004. Ulbert Silalahi, Studi Tentang IImu Administasi, Guna Widya, Jakarta, 2007.

Sritomo Wigjosoebroto, 1992, Teknik tata cara pengukuran kerja, Edisi kedua, Guna Widya, Jakarta: hal. 2-6.

Sutalaksana, 1979, Teknik tata cara kerja, Jurusan teknik industri ITB, Bandung: hal. 64, 105-106.

Soekarno K. Dasar-dasar Manajeman, Guna Widya, Jakarta, 2003. 